\title{
PRÁTICAS DE LAZER DO POVO INDÍGENA TREMEMBÉ
}

Recebido em: 02/02/2018

Aceito em: 06/11/2018

\author{
Arliene Stephanie Menezes Pereira ${ }^{1}$ \\ Daniel Pinto Gomes ${ }^{2}$ \\ Simone Oliveira de Castro ${ }^{3}$ \\ Instituto Federal de Educação, Ciência e Tecnologia do Ceará \\ Fortaleza-CE - Brasil
}

RESUMO: Verifica, descreve e traça um perfil, através do método etnográfico, das práticas de lazer do povo indígena Tremembé de Almofala, no município de Itarema, estado do Ceará. Para a coleta dos dados utilizaram-se entrevistas estruturadas, relatos, fotos e vídeos, abrangendo 78 pessoas de 04 a 87 anos, indígenas residentes na praia de Almofala. Através da análise dos dados foi apontado como principais resultados o perfil, a singularidade e a descrição do lazer, bem como traços da cultura inseridos nesse processo; verificando que ainda há uma grande diversidade dessas práticas, com o sentimento de grupo envolvido em várias das atividades.

PALAVRAS CHAVE: Atividades de Lazer. Tremembé. Indígenas.

\section{PRACTICES OF LEISURE OF INDIGENOUS PEOPLE TREMEMBÉ}

ABSTRACT: It verifies, describes and traces a profile, through the ethnographic method, of the leisure practices of the Tremembé indigenous people of Almofala, in the municipality of Itarema, state of Ceará. For the data collection, structured interviews, reports, photos and videos were used, covering 78 people from 04 to 87 years old, indigenous residents in the beach of Almofala. Through the analysis of the data, the profile, singularity and description of the leisure as well as traces of the culture inserted in this process were pointed out as main results; verifying that there is still a great diversity of these practices, with the group feeling involved in several of the activities.

KEYWORDS: Leisure Activities. Tremembe. Indigenous People.

\footnotetext{
${ }^{1}$ Mestranda em Educação Física-UFRN. Docente do Instituto Federal de Educação, Ciência e Tecnologia do Ceará. Grupo de pesquisa Corponexões: corpo, cultura e sociedade-IFCE.

${ }^{2}$ Doutorando em Educação-UFC. Docente do Instituto Federal de Educação, Ciência e Tecnologia do Ceará. Rede Cedes-Núcleo Ceará.

${ }^{3}$ Doutora em Sociologia. Docente do Instituto Federal de Educação, Ciência e Tecnologia do Ceará. Grupo de Estudos em Cultura Folclórica Aplicada-IFCE.
} 


\section{Introdução}

O presente trabalho faz uma análise da singularidade das práticas de lazer dos índios Tremembé, que residem em Almofala, mais especificamente os moradores da localidade Praia, no Município de Itarema, estado do Ceará. Existem outros povoados, em mais dois municípios do mesmo estado: Acaraú e Itapipoca. O povoado de Almofala situa-se entre os rios Aracati Mirim e Aracati-Açu. Estas terras foram doadas através de Carta Régia do Governo Português, datada de 08/01/1697 e tinha como objetivo a fixação e redução do território Tremembé (GOMES; VIEIERA \& MUNIZ, 2007.).

O povo Tremembé é uma das 12 tribos que existem no Ceará. Esse grupo indígena é conhecido por seus exímios artesãos, e pela fabricação do mocororó, bebida feita de caju e pela sua dança particular, o Torém, que lhes trouxe diferenciação e notoriedade social.

Para Dumazedier (1976) o lazer é um conjunto de ocupações às quais o indivíduo pode entregar-se de livre vontade, seja para repousar, seja para divertir-se, recrear-se e entreter-se, ou ainda, para desenvolver sua informação ou formação desinteressada, sua participação social voluntária ou sua livre capacidade criadora após livrar-se ou desembaraçar-se das obrigações profissionais, familiares e sociais. Ou seja, compreende-se aqui que o lazer está associado à disponibilidade do sujeito ao tempo livre. Porém com relação aos indígenas, ainda existem escassas pesquisas sobre qual o significado de lazer ou que práticas os indígenas têm como lazer. Sendo difundido um estereótipo negativo de que o índio é preguiçoso.

Nessa direção foi que o problema dessa pesquisa se definiu, propondo-se a dar encaminhamento às seguintes questões: Quais os tipos de práticas que constituem lazer e trabalho entre os índios Tremembé? Qual a relação entre essas práticas? Por que existe 
uma singularidade das atividades? Essas atividades são definidas a partir de sua cultura? Assim, identificou-se entre os Tremembé o lazer como um fator físico, espiritual, cultural, histórico, social, ideológico, econômico e psicológico. Dando relevância às características culturais próprias a essa comunidade, dos tipos de atividades desenvolvidas, além de compreender suas relações com a cultura. Corroborando com o que afirma Edward Tylor ${ }^{4}$ (apud LARAIA, 1986) que definiu cultura como sendo um todo complexo que inclui conhecimentos, crenças, arte, moral, lei, costumes e todas as capacidades e hábitos adquiridos pelo ser humano como membro de uma sociedade $\mathrm{E}$ por fim, desmistificando-se alguns tabus, como o da ociosidade exagerada dos indígenas.

A inserção da pesquisadora dentro da comunidade indígena, foi com a finalidade de recolher dados, fotos, vídeos e entrevistas, que para isso foi utilizado como procedimento o método etnográfico. Geertz (1989, p. 29) diz que "o etnógrafo 'inscreve' o discurso social: ele o anota. Ao fazê-lo, ele o transforma de acontecimento passado, que existe apenas em seu próprio momento de ocorrência, em um relato, que existe em sua inscrição e que pode ser consultado novamente”.

A pesquisa etnográfica é do tipo descritiva, visto que pretende apenas identificar e descrever os fatores sociais da comunidade. Foram entrevistadas um total de 78 pessoas, entre crianças, adultos e idosos, num total de 12 dias. Exatamente nos dias 02/10/2009 à 13/10/2009. Nas localidades de Almofala, Varjota, Saquinho, Urubu, Camboa da lama, Lameirão, Panã e Mangue Alto. Onde foram observadas e posteriormente analisadas as práticas de lazer observadas dentro da comunidade indígena Tremembé de Almofala.

\footnotetext{
${ }^{4}$ TYLOR, Edward Burnett. Primitive Culture. Londres, John Mursay \& Co. 1871.
} 


\section{Quem são os Índios Tremembé?}

Este grupo ameríndio vive atualmente no litoral oeste do estado do Ceará com 25 povoados, em três municípios: Itarema, Acaraú e Itapipoca. E é registrado em vários relatos da época colonial do Brasil, sendo chamados de Tremembé, Teremebé, Taramambé, Tramembé, Taramembé, Tramambé e até de Tapuios (SOBRINHO, 1951). A origem do nome vem:

[...] dos 'tremedaú', que é uma espécie de córrego de lama movediça, coberto por água escassa. Quando os índios eram perseguidos, entravam nos 'tremedaú', e como sabiam afundar na lama, conseguiam sair em outra localidade. Os soldados ou capangas que os perseguiam, porém, não possuindo a mesma destreza, afundavam e morriam (GOMES; VIEIRA \& MUNIZ, 2007. 2007. p.45).

A aldeia mais importante, a de Almofala, fica distante $190 \mathrm{~km}$ de Fortaleza

(capital do estado do Ceará), onde hoje vive o atual cacique Seu João Venâncio.

Almofala é relatada pelos próprios índios vinculando o nome a sua própria história.

Segundo os nossos antepassados, que eles passam pra gente, o nome Almofala né, surgiu de quando os europeus chegaram aqui. Então, era muita mata né, na beira da praia, também. E aí eles ficaram né. Os europeus ficaram caminhando nessa região né, da praia. E aí eles ouviam apenas as vozes né, porque os índios né, os nativos estavam dentro da mata de lá observando quem tava e quem passava na praia. Então eles diziam que iam embora porque ali só alma falava. Aí eles botaram o nome de Almafala (José Getúlio dos Santos - Professor da escola indígena diferenciada Maria Venâncio). ${ }^{5}$

Essa história contada pelo educador se passa em 1501 com a chegada dos portugueses no aldeamento de Almofala (CEARÁ , 2007a). O professor e antropólogo Valle (2005, p.192) também descreve um pouco da história da aldeia:

A situação de Almofala compreende a vila homônima, onde existiu

\footnotetext{
${ }^{5}$ Entrevista realizada em 05/10/2009 em Itarema/CE.
} 
um aldeamento indígena até meados do século XIX, e um grande número de localidades. Tem valor simbólico central para os Tremembé, sobretudo para entender os significados do que se conhece por Terra da Santa ou Terra do Aldeamento, que teria sido doada aos índios no passado.

Atualmente esses indígenas enfrentam muitas questões sobre a terra com fazendeiros, grandes empresários e com a exploração turística do litoral, não só em Almofala, mas também nas outras localidades. Os Tremembé forneceram um rico material e várias referências para os escritores e cronistas do século XVII, não apenas pelo modo particular de como viviam, como também pelas lutas e perseguições que moveram os colonizadores portugueses e outros índios. A história desse povo é relativamente longa e houve personagens como aventureiros, cronistas e colonizadores (espanhóis, portugueses e franceses), e administradores das capitanias do Ceará e do Maranhão assim como cita Pereira (2010):

Dessa cultura e somatologia, chegaram até nós, escassos elementos, porém nada de suas origens ou proveniências. Apesar disso, ao longo de todos estes anos, esses índios conservaram a produção do mocororó, bebida feita do caju, utilizada em festas, rituais e no cotidiano; e também a sua dança, o Torém, que ao longo de seu processo de organização e mobilização étnica, tem sido o seu principal sinal diacrítico, referência de singularidade. Conservado fervorosamente por muitos, e já esquecida por alguns índios mais jovens (p. 20).

De acordo com Sobrinho (1951) encontram-se relatos do cronista Pedro Mártir de Algéria sobre esse povo, ao descrever a expedição de Vicente Yanez Pinzón, de dezembro de 1500 a setembro de 1501 . Bem como também de registros que um ano e meio depois, Américo Vespúcio (que viera na primeira expedição exploradora da costa brasileira em 1501 pelo rei de Portugal) descreveu episódios ocorridos em terras de pleno domínio Tremembé. Durante todo o século XVI, esse povo foi muito explorado por franceses e portugueses. E no século XVII sofreram nas mãos dos portugueses que 
se apoderaram das terras do Ceará. Esses quando não travavam guerra contra os indígenas, aliavam-se aos mesmos, fundando os povoados e se fortificando cada vez mais. Onde somente no século XIX, em 1857, suas terras foram doadas aos indígenas da povoação antiga, mas acabaram sendo invadidas pelos latifundiários.

Em razão do contato secular com outras sociedades e da discriminação sofrida, que resultaram em profundas mudanças culturais, a língua e a autodenominação dos Tremembé foram esquecidas. Ainda hoje eles conservam vários de seus costumes como o de pintar as paredes das suas casas, a fabricação da cerâmicas e a pintura delas por meio de uma tinta natural o toá (que é extraída da lameira dos rios), confeccionam bijuterias de material rústico (como conchas, búzios, sementes, penas e cipós), pintam seu próprio corpo com a tinta do jenipapo, e tem atividades como a agricultura, a tecelagem e a pesca artesanal. No Ceará a maioria das etnias indígenas dança o Toré, mas somente os Tremembé dançam o Torém, que se difere, numa forma bem simplista de descrição, pelo ritmo lento e pelo canto em língua ameríndia.

Esse povo nos últimos anos teve grandes conquistas. Além do reconhecimento das escolas indígenas diferenciadas, tiveram também formada sua primeira turma de docentes do Magistério Indígena Tremembé Superior (MITS), pela Universidade Federal do Ceará (UFC). Mas são reconhecidos culturalmente, sobretudo, pelo Torém, o ritual ancestral, que faz parte da sua singularidade cultural.

\section{O Lazer dos Tremembé}

"Nas horas vagas a gente se diverte, sim. Porque a gente trabalha em grupo. Então nas horas vagas. A gente nunca tá sozinho, tá sempre em grupo. Então nas horas vagas a gente aproveita pra se divertir. O 
que não falta é diversão pra gente" (Maria Neide Teles Santos, educadora indígena) ${ }^{6}$.

Segundo Dumazedier (1976), o lazer tem como função a tentativa de fazer com que o sujeito se desligue temporariamente de suas obrigações, e que o mesmo se dá no tempo à margem das obrigações sociais, e que esse tempo varia de acordo com a forma e intensidade de engajamento do indivíduo nas obrigações.

A partir do conceito de lazer formulado por Dumazedier (1976), foi estipulada a pergunta chave para o questionamento sobre o lazer dos índios Tremembé, que era o que eles realizavam em seu tempo livre. Todos os entrevistados responderam que praticavam mais de uma atividade para o lazer. De acordo com eles as principais atividades são brincar e passear. Que obtiveram respectivamente, 23 e 21 respostas.

Gráfico 1: O que você faz em seu tempo livre?

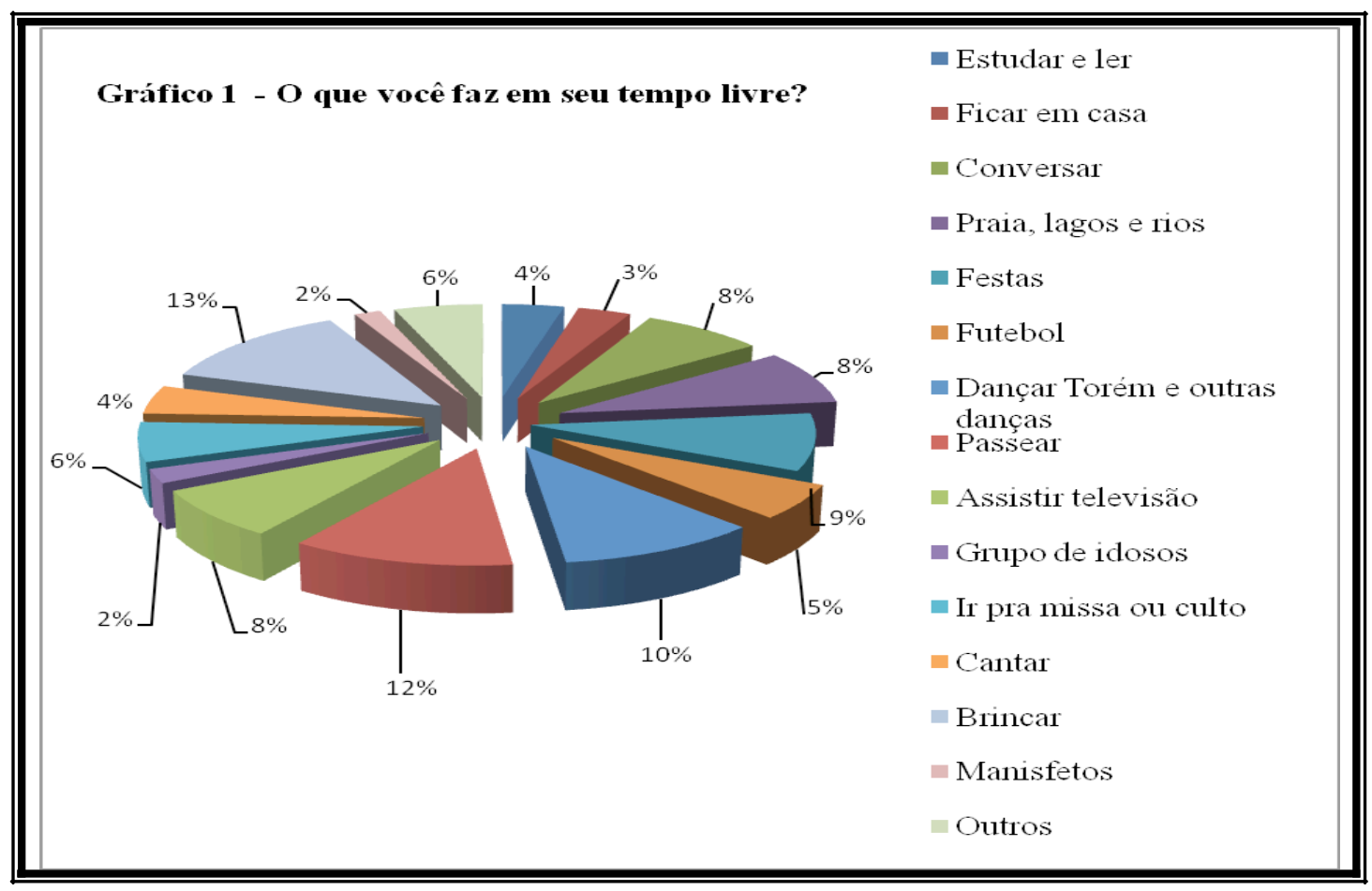

O gráfico nos revela a amplitude de atividades praticadas pelo grupo em seu

\footnotetext{
${ }^{6}$ Entrevista realizada em 05/10/2009 em Itarema/CE.
} 
tempo livre, revelando também a inserção de outras culturas dentro da comunidade, através dos dados demonstrados nas respostas aos quais respondiam que "assistiam televisão", jogavam futebol e participam de cultos ou missas. A maioria já possui televisão em suas casas sendo um lazer muito praticado principalmente por mulheres em todas as faixas etárias. Para tanto, esta pesquisa de cunho etnográfico observou várias atividades que são peculiares aos índios Tremembé, e que serão descritas a seguir.

\section{Espaços de Lazer}

Os espaços de lazer são os mais diversificados, sendo os espaços na natureza, os que estão em maior número: Matas, Lagoas, Rios, Praia, Casa, Escola, Campos de futebol (areia), Igrejas, Mangues e Córregos. Esses espaços naturais a cada dia que passam são ameaçados pela ação do homem, entre eles posseiros e grileiros. Acabando com os espaços naturais que esses indígenas têm pra se divertir e também para trabalhar. As matas são ameaçadas pelas derrubadas, queimadas, pasto para gado, agricultura e ocupação para construção civil. Os rios, o mar, córregos e lagoas são ameaçados pela poluição, entrada de areia por cima dos rios e a construção de açudes particulares. Foi visto inclusive a ação dos posseiros num campo de areia, que era o antigo campo de futebol usado pelos índios que havia sido cercado e a areia revolvida.

Dentre os espaços de lazer, o que mais se destaca, é a escola indígena diferenciada Maria Venâncio. Nela as crianças brincam no pátio e na sua quadra que é em formato circular. Também conversam em seus corredores, dançam o Torém e se divertem com o transporte escolar. Na escola não existem regras institucionalizadas, mas regras de ética e de boa conduta seguidas pelo bom senso de cada um. A escola também é um ponto de lazer, pelo fato de muitos de seus alunos morarem próximos. 
Tornando-se também um ponto de encontro por um grupo de idosos.

\begin{abstract}
"Quando é sábado a noite tem o grupo de idosos. 24 idosos e aí a gente, lá leva pra várias outras escolas. E lá tem um forrozim, dança o Torém, tem a dança do Caçador. Quer dizer é uma atividade pra mim, só que no mesmo instante é lazer. Tanto pra mim quanto pra eles" (Maria Aurineide dos Santos - Diretora da Escola Maria Venâncio $)^{7}$.
\end{abstract}

Esse grupo é composto por 24 idosos e para eles as atividades desenvolvidas são uma espécie de Terapia Ocupacional, tudo dirigido pela Diretora da escola. Dançam forró e também outras danças próprias do grupo indígena, se exercitam e pintam. Vindo de várias localidades e se divertem ao fazerem as atividades que são propostas.

\title{
Brincadeiras
}

Além do Torém, que é considerado e chamado pelos adultos de brincadeira, as crianças costumam brincar de elástico, amarelinha, pular corda, brincar de casinha, passar o anel, telefone sem fio, esconde-esconde, adedonha, e as lutas livres. E o Pia que é uma espécie de pega-pega. As parlendas, as adivinhas e as músicas estão no diaa-dia das crianças, muitas relatando nomes de animais.

Nota-se que nas brincadeiras cantadas tem-se um processo de inserção de outras culturas, e ainda uma forte influência da televisão que já é bastante difundida entre eles.

O predomínio de brincadeiras junto à natureza, nos rios, em bandos, é outra característica do modo de brincar indígena. Entre os Tremembé as brincadeiras que envolvem o banho no mar também são comuns devido à sua localização no litoral do

\footnotetext{
${ }^{7}$ Entrevista realizada em 05/10/2009 em Itarema/CE.
} 
estado, além das brincadeiras na areia da praia, como guerra de areia, se enterrar, catar conchas e construção de esculturas.

Além de outras brincadeiras da natureza, como subir nas árvores e brincar com os animais, que são patos, galinhas, pintos, pássaros, cachorros, peixes, siris, rãs, insetos, gatos e sapos, as crianças parecem ter uma grande intimidade com os bichos, também os imitando-os. Esse tipo de imitação foi visto várias vezes e é muito comum nesse universo das brincadeiras; imitando também os mais velhos e a eles mesmos.

\section{Brincadeiras sazonais}

A comparação e análise dos dados indicam que as práticas lúdicas acompanham as transformações ocorridas na natureza, nos modos de produção, comunicação e de organização social de cada grupo. Dessa estreita ligação evidenciam-se as marcas sazonais, ou os fatores que favorecem ou interferem no brincar. Tais marcas não são localizadas apenas nas estações climáticas, mas nas significações simbólicas diferentes. Constatou-se a existência de temporadas de brincadeiras, apesar das alterações do repertório lúdico e das condições em que é praticado. Como brincar de subir nos cajueiros, por que está na época do caju, só brincar no mar quando a maré está baixa, banho em rios, córregos e lagoas nas cheias, banho de chuva, brincar com as sementes na época de cada árvore, colocar pétalas de rosa nas unhas fingindo estarem de unhas pintadas, colher frutos e caçar alguns animais.

Nunes (1999), ao descrever uma série de brincadeiras infantis da tribo Xavante, diz que as crianças, quando brincam, estão contextualizando e elaborando o contexto social em que vivem. Seu artigo equaciona os aspectos do cotidiano e a atividade 
lúdica através da constatação de que a brincadeira faz parte do dia-a-dia e se presta a resultados reais. Além disso, a autora parte das brincadeiras para evidenciar as dimensões da cultura e da vida social, como tempo e espaço, presentes nas brincadeiras sazonais. Espaço e tempo são apenas algumas das categorias analíticas analisadas e que poderiam ser exploradas a partir de estudos sobre o aspecto lúdico infantil.

\section{Brinquedos}

Freyre (2000) diz que de tradição indígena ficou no brasileiro o gosto pelos jogos e brinquedos imitando animais. Entre os mais comuns está o cavalinho e o boi. $\mathrm{Na}$ comunidade pesquisada outros brinquedos também são muitos comuns como a bola, bonecos de super-heróis, bonecas, carrinhos, estilingues, damas, a bicicleta e outros brinquedos feitos de sucata. "Eu brinco de cavalo, de boneco de Batman, de tigre. Eu brinco. Quando eu vô pra praia eu brinco, levo meus brinquedos." (Joab do Nascimento Santos, 04 anos, aluno do ensino infantil da escola Maria Venâncio) ${ }^{8}$. Os bonecos de super-heróis, por exemplo, trazem a evidenciação da inserção da mídia e de outras culturas de massa também inseridas na cultura desse povo.

Entre as meninas o brinquedo mais comum é a boneca. Com a qual, meninas de até 14 anos relatavam-me que brincavam. "Eu brinco mais as minhas colegas. De bola, de boneca. Só essas brincadeiras mesmo." (Maria Joana Santos Carneiro, 14 anos, estudante da $4^{\circ}$ série da Escola Maria Venâncio) ${ }^{9}$

As crianças utilizam conchas, búzios, galhas de árvores, folhas, flores, castanha de caju, sementes, pedras e várias outras coisas retiradas da natureza como brinquedos.

\footnotetext{
${ }^{8}$ Entrevista realizada em 04/10/2009 em Itarema/CE.

${ }^{9}$ Entrevista realizada em 04/10/2009 em Itarema/CE.
} 
Brougère (2004) discute essa questão do uso dos brinquedos pelas crianças e afirma que estão ligados às transformações do mundo, participam da construção da infância, que é vivida diferentemente conforme a época, cultura e classe social. O que se nota mais claramente é a divisão dos brinquedos pelas crianças, brincando sempre em grupo. Não se presenciou qualquer tipo de apego material ou traços do consumismo e de egoísmo através dos brinquedos, mas sim uma repartição muito bem organizada.

\section{Jogos indígenas}

Huizinga (1971) diz que o jogo é uma categoria absolutamente primária da vida, tão essencial quanto o raciocínio, e o define como uma atividade voluntária exercida dentro de certos e determinados limites de tempo e espaço, segundo regras livremente consentidas, mas absolutamente obrigatórias, dotado de um fim em si mesmo, acompanhado de um sentimento de tensão e alegria e de uma consciência de ser diferente da vida cotidiana

Entre a comunidade é comum a presença de jogos mais modernos como o futebol. O futebol é visto todos os dias; a maioria dos seus jogadores são homens, mas já se vê muitas mulheres, principalmente adolescentes. Mulheres também jogam junto com homens. Eles brincam em campos de areia improvisados ou na quadra da escola. $\mathrm{Na}$ quadra, que é de formato circular, as crianças jogam com uma bola de tamanho inferior à da convencional. Essa característica dos desportos inseridos em uma etnia específica classificou-se como etno-desporto:

O Etno-Desporto indígena está, então, fundamentado na possibilidade das culturas adaptarem e transformarem suas próprias tradições e adaptarem e transformarem as tradições advindas do contato. Mais que adaptar e transformar, o Etno-Desporto expressa o processo de ressignificação de valores culturais e uma reinserção 
com o mundo dos brancos: a criação - pela mimesis - de uma segunda natureza (FASSHEBER, 2006, p. 91).

No dia 7 de setembro também fazem jogos indígenas competitivos entre as aldeias. São a corrida, atirar com arco e flecha, brincadeira do tatu, brincadeira de quebrar o pote com os olhos vendados, mata o pato, cabo de guerra e o arremesso de lança. Como afirmou Fassheber (2006) esses desportos têm um significado dos valores culturais indígenas numa relação com outras culturas, criando características peculiares como, por exemplo, a escolha da miss Tremembé que é uma espécie de desfile onde as índias estão caracterizadas. Misturando desse modo a cultura Tremembé e outras culturas.

\section{Contação de histórias}

Quando estão reunidos sua atividade mais comum é a contação de histórias, até mesmo entre os adultos, os quais muitos relataram que gostam de juntar-se as famílias ou sentarem-se em frente as suas casas para conversarem com amigos e vizinhos.

Geralmente a gente tá reunido, conversando, botando o papo em dia. E cada coisa que os mais velhos falam a gente diz que isso aí é como aprendizado pra mim. Então isso é muito bom. Porque eles estão me passando coisas novas (Maria Liduína dos Santos, professora da Escola indígena Maria Venâncio) ${ }^{10}$.

Suas conversas também versam sobre os seus antepassados e como disse a educadora Liduína, na conversa sempre se está aprendendo algo, porque eles sempre estão conversando com os mais velhos. Segundo POVOS INDÍGENAS DO BRASIL (1991) dos elementos mais importante da semântica da etnicidade Tremembé seria a memória social. Há rememoração do passado, de fatos acontecidos, de pessoas

\footnotetext{
${ }^{10}$ Entrevista realizada em 07/10/2009 em Itarema/CE.
} 
falecidas, de "histórias" contadas pelos pais e avós. Além disso, narrativas orais tradicionais podem ser emitidas combinando os testemunhos do passado vivenciado pelos Tremembé. Esse embaralhamento de eventos históricos e imaginários provém da maneira como eles concebem e apreendem o tempo.

Os índios Tremembé são contadores de histórias contumazes. A quantidade e variedade das narrativas que gostam de lembrar fica logo evidente a qualquer visitante que chegue a Almofala, dispostos a conversar sobre assuntos que digam respeito ao passado da aldeia dos índios, cujos descendentes ali vivem. Essa tradição oral Tremembé abarca uma sequência de episódios que retrocedem à fundação da missão onde foram aldeados por missionários leigos, em 1702, e chegam até o presente. Emitem e formulam relatos, juízos narrativas orais, enunciados, histórias e lendas. Podiam ser também comentários, anedotas e provérbios. Dentre os diversos elementos semânticos, havia uma enorme discussão sobre as antigas "matas", sobre a distinção entre "índios brabos" e "mansos". Aludiam com frequência à vulgata da "avó pegada a dente de cachorro", que tinha sido "amansada" (POVOS INDÍGENAS DO BRASIL, 1991).

Gostam tanto de histórias que remontam sua história, como histórias da vida cotidiana e ainda histórias de terror, às quais chamam de história assombrante. Entre histórias que são contadas, estão as que falam dos seus encantados, que eles relatam serem pessoas que foram encantadas desde o começo do mundo. Como o Curupira e o Caipora, que vive nas matas e o Guajara, entidade mítica que protege os manguezais. Para o povo Tremembé o manguezal, o rio, o mar são entes vivos protegidos por encantados. Às vezes eles juntam-se ao redor da fogueira só para divertirem-se contando essas histórias. 
Dentre as narrativas orais tradicionais, deve-se destacar, sobretudo, a "história da Santa de ouro". Esse acontecimento fala na descoberta de uma imagem de ouro nas proximidades do rio Aracati-mirim e que foi erguida uma pequena capela no local, em torno da qual cresceu e deu origem ao povoado de Almofala. Logo depois foi construída a Igreja de Nossa Senhora da Conceição dos Tremembé, que os próprios índios ergueram para substituir a pequena capela da santa e que lá permanece até hoje. São histórias do "tempo dos antigos", os "índios velhos", e suas primeiras experiências de convivência com o mundo dos brancos. Segundo dizem, a "terra do aldeamento" ou "terra da santa" foi doada aos índios pelos portugueses que ali se encontravam, mediante um acordo feito entre os índios e a rainha de Portugal, que envolveu a troca da imagem de ouro por outra, feita de madeira e a construção da igreja. Por meio da narrativa, os Tremembé das situações de Almofala, Tapera e Varjota afirmavam a antiga doação da terra onde viviam, justificando, portanto, o seu "direito" à terra, que era definida a partir de categorias territoriais similares como "Terra da Santa", "Terra do Aldeamento" ou "Terra dos Índios". Essa narrativa era bem conhecida pelos regionais. Pode ser tomada como uma tradição oral, e não deve ser vista como sendo de conhecimento exclusivo dos índios. (POVOS INDÍGENAS DO BRASIL, 1991)

São exímios contadores de piadas; riem bastante e se divertem, gostando também de zombar, que eles chamam de mangar, de várias coisas. Deles mesmos, dos outros. Foi visto um episódio, em que o Cacique João Venâncio estava presente, no qual um pescador adormeceu de tanto tomar o mocororó. Os homens que ali estavam reunidos, bebendo mocororó e comendo, colocaram flores em sua cabeça, gestos com as mãos. Se divertiram e zombaram bastante desse pescador. Inclusive as crianças zombam bastante de seu transporte escolar, um pau-de-arara, que eles apelidaram de 


\title{
cafuringa.
}

\begin{abstract}
"A cafuringa é um bicho que dentro dele é quebrado. Tem uma escadinha na cafuringa que os meninos sobe, e leva os meninos pro Urubu. A zuada que a cafuringa faz é igual a da topic. Ela leva e trás o pessoal. Eu mango" (Sabrina dos Santos Nascimento - 6 anos Aluna da Alfabetizaçao da escola Maria Venâncio) ${ }^{11}$.
\end{abstract}

A cafuringa transporta crianças e adolescentes que estudam na Escola indígena Maria Venâncio até as localidades do Urubu e Saquinho. Tanto no período da manhã quanto da tarde. No trajeto que a cafuringa faz todos os dias foi observado que é um ponto de conversas das crianças e adolescentes, que falam sobre suas brincadeiras, a vida cotidiana, a escola e seus romances.

\section{Danças}

A dança exprimi os sentimentos e as emoções da humanidade. O povo precisa antes de tudo de liberdade e a dança não é outra coisa senão a expressão da liberdade. Entre essa etnia a dança é vista também como um elo de união com as gerações passadas e uma ponte de integração com as famílias da praia e de outras aldeias de quem são parentes. No passado eles se divertiram em muitas noites de lua nova e cheia cantando e dançando. Quando não tinha lua, dançavam no claro de uma fogueira o Torém, a Bulieira, Aranha e muitas outras.

A dança mais conhecida entre os Tremembé é o Torém, também chamada de brincadeira dos índios velhos, que traz uma expressão da unidade grupal. De acordo com Oliveira Jr (1998), os primeiros registros e informações sobre a prática do Torém remontam à segunda metade do século XIX. O historiador Antônio Bezerra (1965) ao

\footnotetext{
${ }^{11}$ Entrevista realizada em 07/10/2009 em Itarema/CE.
} 
escrever sobre a história do Ceará, menciona, em sua visita à região da Ibiapaba, a presença de um grupo de indivíduos que tinha por hábito se vestir e dançar o Torém. Segundo Povos indígenas do Brasil (1991), O Torém era visto como uma dança folclórica organizada pelos caboclos, que são os descendestes de índios. Tendo um significativo valor porque representava a sobrevivência cultural e étnica, tendo este significado até hoje. Nesse sentido, essa dança passou a ser considerada paulatinamente como manifestação folclórica original, o que geraria efeitos sociais, inclusive, na sua valorização cultural na região. Assim, o interesse intelectual articulou-se a uma crescente apropriação do Torém por parte de políticos regionais, considerando as potencialidades atrativas da "dança" em seus eventos públicos. Diversas vezes, a dança foi apresentada em festas de santos padroeiros e também de candidatos diversos às prefeituras dos municípios próximos de Almofala. Era mantido principalmente por indivíduos articulados por vínculos próximos de parentesco, de compadrio e de vizinhança, considerados como os verdadeiros conhecedores da tradição. Pode-se notar, portanto, que a dimensão política que envolvia a dança estava, então, mais próxima, por um lado, de práticas clientelistas sistemáticas e de outro, de uma construção cultural bastante peculiar por parte de pesquisadores e folcloristas do que realmente de uma mobilização política de perfil étnico.

A descrição do Torém seria a de uma dança de roda, dirigida pelo cacique João Venâncio que bate o pé com uma pancada forte no chão, comandando os dançarinos, que são homens e mulheres. Esses movimentos são marcados sonoramente por um maracá. No centro do círculo, fica uma bacia com o mocororó, aguardente de caju azedo que é servido aos participantes. 
Aqui é o vim do caju que nós faz né. Pra quando nós for beber. Pra quando nóis for brincar o Torém que é a nossa cultura. Aí nóis bebe, pra começar a brincar. Aí nóis bebe este vim (Raimundo José dos Santos, morador da localidade da Praia - Seu caçador $)^{12}$.

Também no centro ficam um ou dois dançarinos, os toremzeiros ${ }^{13}$, que dançam por meio de passos compassados e alguns razoavelmente estilizados. É uma dança mimética sobre frutos e animais nativos, como o guaxinim, a tainha e o caju, onde são cantados versos e refrãos em vocábulos de origem indígena.

Na escola indígena Maria Venâncio, o Torém é dançado todos os dias no período da manhã e da tarde, antes de começar à aula. Essa dança acontece todos os dias nos horários de 08:00 horas e 13:00 horas no pátio coberto. Os Tremembé possuem muitas outras dançam entre elas: Bulieira, Aranha, São Gonçalo, Caninhaverde, Salomeu, Festival dos Santos, Rêso, Caçador, Coco de roda. (CEARÁ, 2007b.). A dança do caçador é dançada por Raimundo José dos Santos mais conhecido como Seu caçador. Na qual ele mesmo relata: “Meu nome é Raimundo José dos Santos, mas meu apelido me chamo Caçador. Tenho 67 anos. E ainda danço o Torém e pra dançar o caçador é comigo mesmo." (Raimundo José dos Santos, morador da localidade da Praia - Seu caçador) ${ }^{14}$

\section{Rituais}

Rituais, eventos especiais, eventos comunicativos ou eventos críticos são demarcados em termos etnográficos e sua definição só pode ser relativa - nunca absoluta ou a priori; ao pesquisador cabe apenas a sensibilidade de detectar o que são, e quais são, os eventos especiais para os nativos (sejam "nativos" políticos, o cidadão comum, até cientistas sociais) (PEIRANO, 2002, p. 8-9).

\footnotetext{
${ }^{12}$ Entrevista realizada em 08/10/2009 em Itarema/CE.

${ }^{13}$ Termo usado para especificar os dançarinos do Torém que ficam dentro do círculo, dançando com passos estilizados (OLIVEIRA JR., 1998).

${ }^{14}$ Entrevista realizada em 08/10/2009 em Itarema/CE.
} 
Para Muller (2000) o momento do ritual serve para reelaborar os valores e tradições culturais em um presente com vista a um futuro. O ritual possui tempo de ocorrência, atores, linguagem, espaço de atuação e ainda, é possível ser observado por quem não participa dele. Nesse processo, a sociedade se coloca historicamente. Citando a importância de um ritual como unidade de observação e experiência concreta. A performance expressiva do ritual reflete a sociedade e a comenta como se fosse um metacomentário.

É preciso ressaltar que as práticas espirituais não fazem parte de um sistema religioso formal, mas de uma cosmologia integrada ao meio ambiente, sendo o ecossistema circundante parte indissociável do modo de vida dos Tremembé. Estes mantêm toda uma tradição oral relacionada ao caráter sagrado da natureza, às crenças e aos mitos. É a oportunidade rara, única, de experimentar uma conexão com o universo mágico em que vivem os povos indígenas.

O Torém apesar de ser uma dança é também um ritual. Na verdade, é um ritual dançado. Durante a dança são servidos vários litros de mocororó. Esse gosto dos índios por essa bebida já era visto pelos portugueses desde a época da colonização, ou seja, os índios já o tomavam. Como é relatado pó Freyre (2000, p. 185) "Dos índios transmitiu-se igualmente ao europeu o complexo do caju - com uma série de aplicações medicinais e culinárias; destacando-se, porém, o seu uso no fabrico de um vinho muito bom, hoje caracteristicamente brasileiro."

Mas essa bebida não é tomada apenas durante o ritual, é tomada durante o dia como uma forma de lazer, principalmente na época do caju. Aproveitando-se essa fartura da fruta. É feito do caju, e não somente o caju azedo. Existem quatro tipos dessa bebida. O primeiro que é aquele caju recém-tirado é o chamado vinho do caju, 
tendo um gosto levemente adocicado. O segundo que é aquele que passa mais algum tempo para dar um gosto mais azedo, já fermentado é a real bebida, o mocororó. O terceiro que é aquele que ainda passa um tempo maior fermentando, já é um pouco forte, e que eles chamam de aguardente de caju. O quarto tipo já é o vinho do caju misturado com alguma bebida alcoólica. E que é chamado de vinho misturado. Seu Raimundo José dos Santos já faz o fabrico do mocororó há muitos anos. Relatando aqui a fabricação desse vinho de caju, misturado com a cachaça. Que hoje já é bastante comum na comunidade.

\begin{abstract}
"Aí eu faço, quando vem os amigos pra cá a gente bebe. Tem um bocado ali já feito. As garrafada. Eu aprendi com a minha avó. Dura é tempo. A gente pode até misturar com outra bibida. Pra num azedar, cum a cachaça faz o vim temperado. Tem ele in natura de um ano pro outro, mas fica mais forte. E agora do mesmo ano é bom, fica forte, mas a gente bebe. Agora ficando dum ano pru outro se num butar a mistura cum a cachaça ou cum outra coisa dentro, ele azeda, fica forte demais e num presta. Agora esse aqui que é dum ano pru outro é diferente. Se misturá ele cum outra bebida ele dura. Dura é anos" (Raimundo José dos Santos, morador da localidade da Praia - Seu caçador) ${ }^{15}$.
\end{abstract}

Existem outros trabalhos de rituais na comunidade como as rezadeiras e os pajés. Esses rituais incluem curas com plantas medicinais e outros rituais gesticulados e cantados. São vários os termos que os membros do grupo lançam mão para se referir a estes rituais: trabalho de mesa, macumba, tundá, trabalho de encantados, entre outros, mas em geral, são apreendidos como práticas de Umbanda. A descrição e análise desses rituais abrem portas para a compreensão de uma religiosidade, possibilitandonos contemplar o universo mitológico e simbólico do mesmo. As mulheres pajés são frequentemente requisitadas para realização de trabalhos de cura e gozam de bastante respaldo perante o grupo indígena, mas, sobretudo pelo fato de que suas narrativas e

\footnotetext{
${ }^{15}$ Entrevista realizada em 08/10/2009 em Itarema/CE.
} 
rituais revelam um universo de seres encantados. As descrições sobre os casos de encantaria, cujos personagens são em geral, princesas, príncipes e fadas permeados por símbolos que nos permitem considerar e entender sobre o modo como os Tremembé estabelecem um cosmos sagrado.

$\mathrm{Na}$ umbanda é cura. Os caboco concentra em mim, e aí cura a pessoa. Usa rermédio. Usa os remédios que eles dizem, que árvire é, que num é. Eu trabalho com um bocado de príncipo e princesa, mas quem me ensina os remédio é os encantado. Eu trabalho só com aquele povo encantado. Também eu tenho alguma corrente que é só de espiritismo, só de isprito. Que quando morre alguma pessoa que é conhecido meu, me chama né, assim (Maria Alves de Sousa - Dona Maria Bela, 68 anos. Rezadeira) ${ }^{16}$.

Essas práticas de cura envolvem uma incorporação de entidades, exercidas pelas pajés mulheres, que são as rezadeiras. A mais conhecida é Dona Maria Bela que mora na localidade da praia. Já a figura masculina do pajé é Luís Caboclo morador da localidade da Varjota que relata um pouco de seu trabalho.

As pessoas que vem pra eu rezar. A pessoa reza. Faz toda aquela coisa. Tenho remédio, píula. Que tudo isso é o segredo. Por isso que a gente é mestre, por conta disso. Porque tudo tem um segredo. Essas píula que eu faço, ela eu só faço uma vez no ano. Só tem dia no ano que eu faço porque feito naquele dia ela cura quatorze qualidade de doença. Aí é um segredo. A gente faz laços espirituais quando as pessoas morrem, cordão eu faço. Tem palavras e etc. É uma coisa bem cultural que é dom. E a gente é setisfeito com isso. Porque tem momento que a gente obra milagre (Luís Manoel do Nascimento Pajé Luís Caboclo) ${ }^{17}$.

Nas tribos o pajé é uma das pessoas mais importantes, por possuir conhecimentos específicos de cura. São pessoas muito procuradas e bastantes respeitadas e conhecidas, além de bastante conscientes de que seu trabalho faz parte da

\footnotetext{
${ }^{16}$ Entrevista realizada em 11/10/009 em Itarema/CE.

${ }^{17}$ Entrevista realizada em 12/10/2009 em Itarema/CE.
} 
cultura dos Tremembé.

\section{Adornação Corporal como Significação da Beleza}

Entre as manifestações estéticas indígenas, a ornamentação corporal ocupa um lugar de destaque, pois abrange dois aspectos fundamentais: a corporalidade e a noção de pessoa associada à construção de suas autoimagens. A corporalidade neste contexto ocupa um lugar de primazia e uma posição organizadora central. O corpo é uma matriz de símbolos e um objeto de pensamento. O corpo é um elemento através do qual se estabelece uma linguagem visual compartilhada. Ao considerar a pintura corporal dos índios, diz Lux Vidal:

A ornamentação e, especialmente, a pintura corporal (...) revelam a cada um as múltiplas facetas de sua pessoa em contraposição a todos os outros indivíduos, no tempo e no espaço: um recurso para a construção da identidade e da alteridade (VIDAL, 1992).

Em dias comuns os índios pintam-se, como preparados às ocasiões rituais nas quais a presença da ornamentação corporal é requisito obrigatório, sem que nenhuma razão imperativa haja para estes pintarem-se ou adornarem-se. Somente para enfeitar, para ficarem bonitos. Eis aí um primeiro plano de significação: o da beleza.

Para as crianças e os jovens índios, serem pintados, sentirem e verem seus corpos ostentando linhas ou círculos geometricamente dispostos e outras figuras, como desenhos de seu cotidiano, significa aprender algo sobre si mesmo, sobre seu lugar no

mundo e sobre os demais. É um processo de aprendizagem e conhecimento expresso corporalmente.

Os índios pintam-se não somente em ocasiões especiais, mas no dia-a-dia. Tanto com caneta, como com urucum, jenipapo. A mais comum é a pintura de caneta 
entre as crianças. A pintura de jenipapo também é bem usual, principalmente entre as jovens adolescentes. A tinta de jenipapo é feita com a frutinha do jenipapo ralada e misturada com álcool. Já o urucum é visto apenas em ocasiões especiais. Pintam com essas tinturas vários desenhos como cocares, cajus, linhas geométricas, círculos e listras.

Apesar da pintura com círculos e outras figuras geométricas já serem bastante comuns na comunidade, essa pintura não é específica desse povo. Como este relato de uma menina Tremembé ao falar sobre a pintura geométrica. "Essa pintura não é dos Tremembé. A nossa é caju, cocar. Mas essas são dos índios também." (Maria Samires do Nascimento Souza, 14 anos) ${ }^{18}$.

Outros tipos de adornos são as bijuterias como brincos, pulseira, gargantilhas, anéis, enfeites de cabelo. Tudo feito de conchas, coco, penas, patas de lagosta e sementes. Brincos no nariz são poucos, mas já existem. Estes adornos já eram usados pelos índios desde antes mesmo da colonização, como é citado por Freyre (2000, p. 190): "Era também o corpo pintado de urucu ou jenipapo; os beiços, o septo, as orelhas perfuradas; batoques, fusos, penas enfiadas nesses orifícios; dentes de animais pendurados ao pescoço". Há ainda as roupas de penas e cocares, que são mais usados em ocasiões especiais. Como as apresentações e a Marcha do 7 de setembro. Essas roupas e outros adornos são fabricados por eles mesmos.

\section{Música e Instrumentos}

O maior contato que eu tenho com a música é no momento do Torém. As músicas do nosso povo, que a gente tá sempre cantando todos os dias aqui na escola. A gente tá sempre cantando todos os

\footnotetext{
${ }^{18}$ Entrevista realizada em 03/10/2009 em Itarema/CE.
} 
dias aqui na escola e é algo que a gente já carrega dentro da gente (José Getúlio dos Santos - Professor da escola Maria Venâncio) ${ }^{19}$.

De acordo com Oliveira Jr (1998, p. 13) a dança do Torém é acompanhada por uma cantata em quadra, falada em língua ameríndia, possível mistura de vocábulos Tupis e Tremembé. Esse idioma materno do grupo não se classifica em nenhum tronco ou família conhecida. As músicas retratam a existência do povo Tremembé. Mostrando que é da natureza que os índios dessa tribo fazem seus mitos e sua cultura. Onde passam criam seus mitos e suas músicas.

As músicas do Torém são as mais cantadas. A música está muito presente, tanto nas brincadeiras como nas parlendas, nas danças e também outras músicas, inclusive românticas. Eles escutam outros tipos de música como o forró, por exemplo.

Assim, vai depender do momento né. Quando eu tô em curtição, mais os amigos, as músicas é aquelas bem antiga, que o pessoal fala aquela música brega né. Gosto muito de escutar forró, mas, sempre esse forrozim, mais assim, pé-de-serra. Luiz Gonzaga, outros que muitas vezes eles falam assim a linguagem popular das pessoas. Diferente de hoje né, desses forró que tem, que as maioria dos forró, da letra de forró hoje, é principalmente defamando as mulheres e as pessoas gostam muito. É claro que às vezes tem um ritmo que faz com que a gente fique agitado né, que chama atenção. Mas, pra questão mesmo de a gente ouvir mesmo. Assim, meditar, refletir, essas outras músicas. Olha, eu vejo que hoje devido muito ao envolvimento das pessoas, principalmente dos jovens, com essa música atual, está muito mais fácil mesmo da gente ouvir essas músicas do que essas músicas críticas. Essas músicas tem muita facilidade pra chegar né (José Getúlio dos Santos - Professor da escola Maria Venâncio) ${ }^{20}$.

No que trata dos instrumentos, os Tremembé fabricam seus próprios, que são usados em suas danças ou rituais. É uma forma de artesanato. Entre esse grupo indígena um dos instrumentos mais conhecido é o "aguaim", espécie de maracá,

\footnotetext{
${ }^{19}$ Entrevista realizada em 05/10/2009 em Itarema/CE.

${ }^{20}$ Entrevista realizada em 05/10/2009 em Itarema/CE.
} 
empunhado pela figura do "chefe" durante o Torém. Apesar de já se ter outros instrumentos como o violão, triângulo, apitos e a zabumba.

\begin{abstract}
Hoje o pessoal utiliza muito... o violão. Utiliza também o zabumba. E, o triângulo também. Sempre nos outros Torém, mas, geralmente aqui na escola a gente utiliza mais a maracá, o instrumento base do Torém. Eu me considero um músico formado pela própria natureza. Que é assim, pra balançar, pra mim balançar ninguém precisou me ensinar. Eu sozim, eu, aprendi sozim, só vendo os outro fazendo né. Da mesma forma também a coisa né, a música pra cantar, só vendo os outros e a gente acaba descobrindo dentro da gente que a gente tem aquele talento praquilo (José Getúlio dos Santos - Professor da escola Maria Venâncio) ${ }^{21}$.
\end{abstract}

\title{
Outras Atividades
}

Na comunidade existem outros tipos de práticas de lazer muito comum. Como ficar apenas se balançando na rede, assistir televisão, desenhar, confeccionar livros e mapas, escrever poemas, escrever músicas e comemorar datas comemorativas. Outra prática que esse povo considera como lazer é comer. Seja nas festas, ou apenas numa roda de amigos, não pode faltar uma boa comida, feita na hora e muita farta. Entre as comidas mais usualmente feitas por eles está o peixe assado, tapioca, manfuê, galinha, castanha assada, galo cozido. Essa comunidade ainda comemora datas festivas, como o sete de setembro, ano novo, natal e aniversários.

\section{Considerações Finais}

Este trabalho foi resultado de uma pesquisa que se estendeu por cerca de dois anos e meio. Os tipos de práticas que constituem lazer entre os índios Tremembé são as mais diversificadas possíveis, existindo diversas relações entre as mesmas e contendo singularidades específicas à comunidade; como as danças, os rituais,

\footnotetext{
${ }^{21}$ Entrevista realizada em 05/10/2009 em Itarema/CE.
} 
brincadeiras entre outras. Verifica-se também que há a inserção de outras culturas em algumas atividades, que envolvem por exemplo o uso da televisão. E através desta reflexão, pode-se analisar que todo esse fenômeno de homogeneização cultural mundial, característico da pós-modernidade, gera certa busca por âncoras simbólicas e originalidade estética. Como as diferentes pinturas corporais já incorporadas dentro da comunidade, o desfile da miss Tremembé, o futebol, a televisão e os brinquedos estilizados.

Constata-se que a cultura indígena Tremembé é interpenetrada por outras dimensões da vida. Por isso, a noção de lazer para eles não é a mesma das sociedades não-índias. Considerando-se processos de ritualização e de atividades de tempo livre peculiares.

Do lado popular, a transformação causada pelos processos globalizantes nos leva a refletir sobre a noção de identidades locais. Na vida urbana, os interesses mercantis cruzam-se com os históricos, estéticos e comunicacionais, onde as manifestações estéticas populares ou primitivas tornam-se passivas à encenação, pois as manifestações estéticas de tais comunidades, como o artesanato, estabelecem relações simbólicas com um modo de vida mais simples, com uma natureza nostálgica. $\mathrm{Na}$ realidade, a cultura indígena sempre representou um dos principais ícones simbólicos das manifestações estéticas deste continente.

No entanto, é interessante ressaltar que o relacionamento destes povos com a sociedade hegemônica foi sempre marcado por muitos conflitos. Apesar dos grandes desafios que os índios enfrentam, a cultura indígena continua presente no Brasil. O que acontece é que muitas pessoas só conhecem os povos indígenas através dos livros de história, e acabam não levando em consideração a riqueza cultural desses povos. E é 
justamente por não terem o valor de sua cultura reconhecido que eles têm seus direitos desrespeitados. Crianças e adolescentes indígenas enfrentam hoje o desafio de aprender e divulgar a cultura de seus povos

\section{REFERÊNCIAS}

BEZERRA, Antônio. Notas de viagem. Fortaleza: Imprensa Universitária do Ceará. 1965.

BROUGÈRE, Gilles. Brinquedos e companhia. São Paulo: Cortez, 2004.

CEARÁ. Povo Tremembé da Varjota e do Córrego João Pereira. In: Raízes que brotam da terra. - Fortaleza: Importec, 2007a.

CEARÁ. Secretaria da educação. Coordenadoria de desenvolvimento da escola. Célula de aperfeiçoamento pedagógico. O livro da vida, v4: Tremembé. - Fortaleza: Importec, $2007 b$.

DUMAZEDIER, Joffre. Lazer e cultura popular. São Paulo: Perspectiva, 1976.

FASSHEBER, Jose Ronaldo Mendonça. Etno-Desporto indígena: contribuições da antropologia social a partir da experiência entre os Kaingang. Campinas, SP: [s.n], 2006.

FREYRE, Gilberto. Casa-grande e senzala. Rio de Janeiro: Record, 2000.

GEERTZ, Clifford: A interpretação das culturas, Rio de Janeiro: Ed. Guanabara, 1989.

GOMES, Alexandre; VIEIRA, João Paulo; MUNIZ, Juliana. Povos indígenas do Ceará: Organização, memória e luta. Fortaleza, Ceará: Editora e gráfica Ribeiro's, 2007.

HUIZINGA, J. Homo Ludens: O Jogo como elemento da cultura. São Paulo. Edusp, 1971.

LARAIA, R. B. Cultura: um conceito antropológico. 7. ed. Rio de Janeiro: Jorge Zahar, 1986.

MULLER, Regina Pollo. Corpo e imagem em movimento: há uma alma neste corpo. Rev. Antropol, 2000, vol.43, no. 2, p.165-193.

NUNES, Angela. A sociedade das crianças A'uwe- Xavante: Por uma antropologia da criança. Lisboa: Ministério da Educação/ Instituto de Inovação Educacional, 1999.

OLIVEIRA JR., Gerson Augusto de. Torém: Brincadeira dos índios velhos. Fortaleza: 
Anna Blume, 1998.

PEIRANO, M. Rituais como estratégia analítica e abordagem etnográfica. In: PEIRANO, M. O dito e o feito: ensaios de antropologia dos rituais. Rio de Janeiro: Relume Dumará, 2002.

PEREIRA, Arliene Stephanie Menezes. Práticas de lazer e trabalho do povo indígena Tremembé de Almofala-CE. 2010. 109 f. Monografia (Graduação em Tecnologia em Gestão Desportiva e de Lazer) - Instituto Federal de Educação Ciência e Tecnologia do Ceará. Fortaleza, 2010.

POVOS INDÍGENAS NO BRASIL. Tremembé. Disponível em: $<$ https://pib.socioambiental.org/pt/Povo:Trememb\%C3\%A9> Acesso em: $10 \mathrm{de}$ Novembro 2009.

SOBRINHO, T. P. Índios Tremembés. Rev. do Instituto do Ceará, Fortaleza: Instituto do Ceará, n.65, 1951.

VALLE, Carlos Guilherme Octaviano do. Compreendendo a dança do torém: Visões de folclore, ritual e tradição entre os Tremembé do Ceará. Revista Anthropológicas, ano 9, vol. 16(2), 2005. Disponível em: <file:///C:/Users/SDD/Desktop/torem\%20revista.pdf> Acesso em: 18 de jun. de 2017.

VIDAL, Lux. Morte e vida de uma sociedade indígena brasileira. São Paulo: Hucitec/Edusp, 1992.

\section{Endereço dos Autores:}

Arliene Stephanie Menezes Pereira

Rua São Bernardo, 214, casa 41. Álvaro Weyne

Fortaleza - CE - 60.335-555

Endereço Eletrônico: stephanie_ce@hotmail.com

Daniel Pinto Gomes

Rua São Bernardo, 214, casa 41. Álvaro Weyne

Fortaleza - CE - 60.335-555

Endereço Eletrônico: danielpintogomes@hotmail.com

Simone Oliveira de Castro

Rua Nossa Senhora do Remédios, 56. Benfica,

Fortaleza - CE -. 60.020-120

Endereço Eletrônico: simone@ifce.edu.br 